\author{
Dominic Schulz \\ Gian-Marco Sarra \\ Ulla B. Koerner \\ Justus G. Garweg
}

\section{Evolution of HIV-1-related conjunctival molluscum contagiosum under HAART: report of a bilaterally manifesting case and literature review}

Received: 3 December 2003

Revised: 26 February 2004

Accepted: 2 March 2004

Published online: 22 June 2004

(C) Springer-Verlag 2004

Financial interests: none

D. Schulz • G.-M. Sarra (

U. B. Koerner · J. G. Garweg

Department of Ophthalmology,

University of Bern, Inselspital,

3010 Bern, Switzerland

e-mail: gian-marco.sarra@insel.ch

Tel.: +41-31-6328516

Fax: +41-31-6320114

\begin{abstract}
Purpose: To present a rare case of bilateral conjunctival molluscum contagiosum (MC) in an HIV-positive individual who had unilateral lesion excision before induction of highly active antiretroviral therapy (HAART), and to discuss the pathophysiological consequences of immune restoration. Methods: Case report: A 40-year-old male Caucasian presented with atypical, bilateral lesions of the limbal conjunctiva due to MC. Before the induction of HAART, nodules in the left eye were excised whilst the single lesion in the right eye was left untouched. Results: The clinical diagnosis of conjunctival MC was confirmed histopathologi-
\end{abstract}

cally. Six months after the induction of HAART, the untouched lesion (right eye) had regressed and there was pronounced local injection of the conjunctiva. MC lesions did not recur after excision (left eye), and signs of inflammation were absent. Conclusion: Conjunctival MC is rare and associated with immune deficiency. To the best of our knowledge, the presented case is the first reported instance of bilateral, multi-lesional MC of the conjunctiva in an HIVpositive patient undergoing HAART. Attention must be paid to the possible complications associated with the restoration of immunocompetence.

\section{Introduction}

Molluscum contagiosum (MC) is caused by a large double-stranded DNA poxvirus, which closely resembles vaccinia [37]. It produces characteristic lesions of the skin, usually of the epidermis alone, which consist of single or multiple pale, waxy, umbilicated nodules, $2-5 \mathrm{~mm}$ in diameter. In the eye region, typical sites of infection are the lids [29] and lid margins, and follicular conjunctivitis or keratitis may occur in conjunction with ocular MC.

These eye-associated manifestations are most frequently encountered in young children [34], the usual sites of outbreak in immunocompetent adults being the external genitalia, the lower abdomen and the upper thigh [42]. The infection is spread by direct contact with infected individuals in showers and swimming pools [59] and on sexual contact [18]. MC is believed to be transmitted by mechanical trauma, infection occurring by skin-to-skin contact and the virus entering through breaks in the epi- dermis or via the infundibular portion of the hair follicle [44]. In healthy individuals, MC is usually self-limited, the often fewer than 20 lesions tending to resolve spontaneously over a period of 3-12 months [30]. In immunocompromised patients, however, lesions may have an atypical appearance $[5,8]$ and be multiple and frequently confluent [4]. MC is known to be a cutaneous marker of advanced HIV infection, a circumstance that has been well documented in both adults and children [23, 28, $33,40,50]$. Individual case reports of atypical MC have been associated with atopic dermatitis [27, 38], sarcoidosis [17], lymphatic leukaemia [46], T-cell deficiency [39], treatment with prednisone and methotrexate [49] and TNF- $\alpha$-antibody therapy [10]. The tendency towards recurrence in immunocompromised patients [47] implies that the immune system is important in the infection's containment and elimination. To date, several cases of ophthalmic MC in AIDS patients have been reported [7, $30,32,47]$, but only two instances of unilateral [6] and 
one of multiple, bilateral [35] lesions of the conjunctiva have been described in such individuals. We herein describe a case of multiple, bilateral lesions of the perilimbal conjunctiva due to MC in an HIV-positive individual and discuss the evolution of the infection under the influence of highly active antiretroviral therapy (HAART), which, to the best of our knowledge, has not previously been described in the published literature.

\section{Case report}

Clinical findings

In January 2002, a 40-year-old Swiss man first tested seropositive for HIV-1. Two weeks later, he was referred to our department for a routine ophthalmological check-up, which included a detailed fundus examination. The patient had an HIV-1 plasma load of 17,150 copies $/ \mathrm{ml}$ and a CD4 T-lymphocyte count of 20 cells/ $\mu$ l, he tested positive for CMV, and clinically he had been staged as HIV C3.

\section{Ophthalmic findings}

Visual acuity was 20/20 in both eyes without correction. Slit-lamp examination revealed tiny white nodules within the perilimbal conjunctiva of each eye: a single one at the 12 o'clock position on the right side (Fig. 1) and four between 5 and 8 o'clock on the left (Fig. 2). Each nodule contained a characteristic central umbilication. No signs of an associated follicular conjunctivitis or keratitis were apparent and perilesional conjunctival injection was minimal. The patient denied the existence of further MC lesions in the genital or abdominal regions. Examination of the fundus revealed a single retinal cotton-wool spot in the right eye. A clinical diagnosis of conjunctival MC and HIV-associated microangiopathy was made.

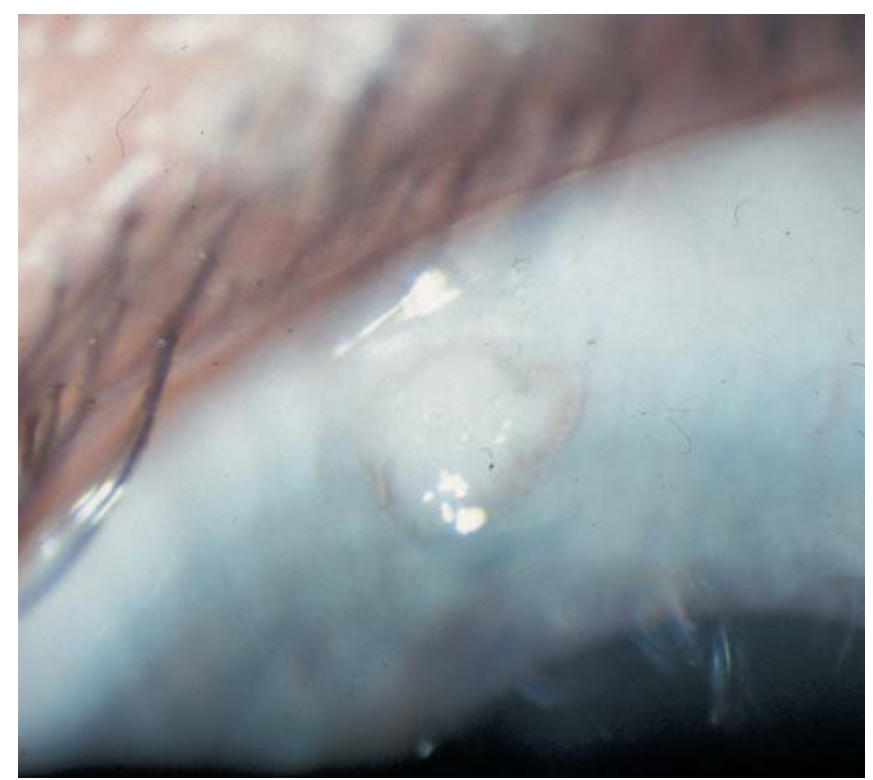

Fig. 1 Right eye. Biomicroscopic appearance of a solitary wartlike lesion without signs of perilesional inflammation

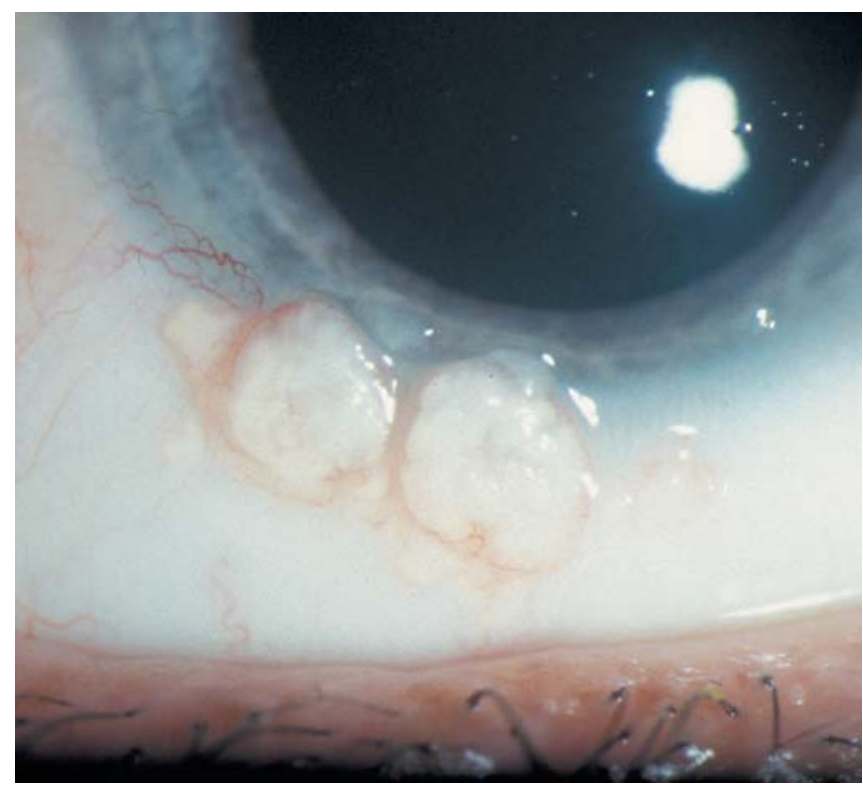

Fig. 2 Left eye. Biomicroscopic appearance of multiple nodular lesions containing characteristic central umbilications. There were no apparent signs of an associated follicular conjunctivitis or keratitis, and perilesional conjunctival injection was minimal

\section{Treatment}

All conjunctival lesions in the left eye were excised under topical anaesthesia; the single nodule in the right eye was left untouched.

HAART was initiated, consisting of Combivir [150 mg of lamivudine and $300 \mathrm{mg}$ of zidovudine (Glaxo, Wellcome)] administered twice daily and Stocrin [200 $\mathrm{mg}$ of Efavirenz (MSD)] three times a day.

\section{Histopathology}

Routine histopathological examination of formalin-fixed, paraffinembedded tissue confirmed the diagnosis of MC (Figs. 3, 4). The conjunctival specimens revealed cup-shaped acanthotic epithelial lesions containing innumerable intracytoplasmic eosinophilic structures, the so-called molluscum bodies. These structures manifested a typical maturation pattern, becoming more basophilic towards the superficial epithelial layers. Neither the lesions nor the adjacent conjunctiva evinced obvious signs of inflammation.

\section{Follow-up}

Six months after the induction of HAART, the untreated lesion of the patient's right eye had undergone remarkable regression and the degree of perilesional conjunctival injection was now marked. In the left eye, MC lesions had not recurred and the excision sites were without apparent inflammation. At this time, the patient had an HIV-1 plasma load of 39 copies/ml and a CD4 T-lymphocyte count of 88 cells $/ \mu$ l. 


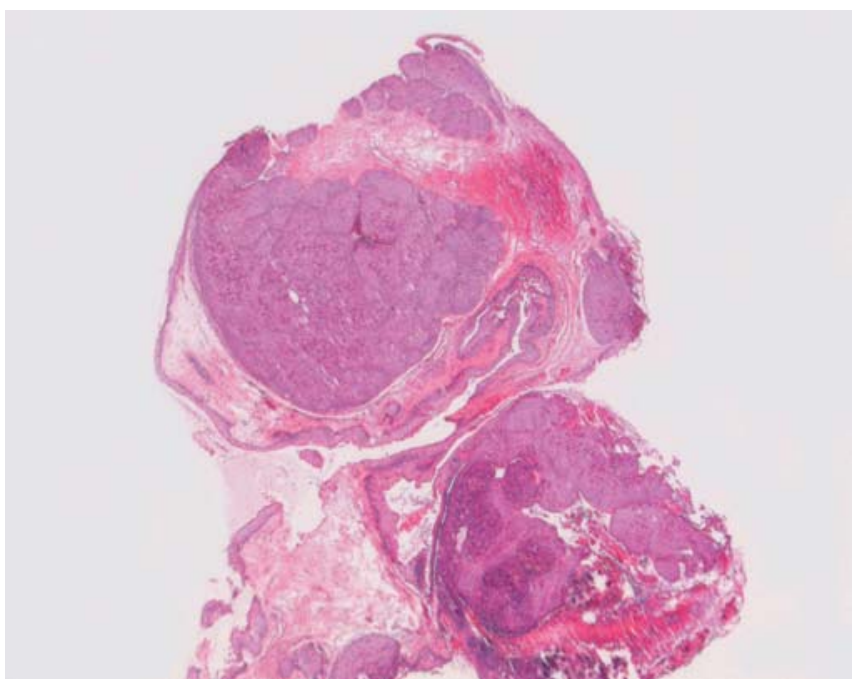

Fig. 3 Histological appearance of lesion excised from left eye. Acanthotic epithelial lesion containing innumerable intracytoplasmic eosinophilic structures. Neither the lesion nor the adjacent conjunctiva showed obvious signs of inflammation. H\&E, $\times 16$

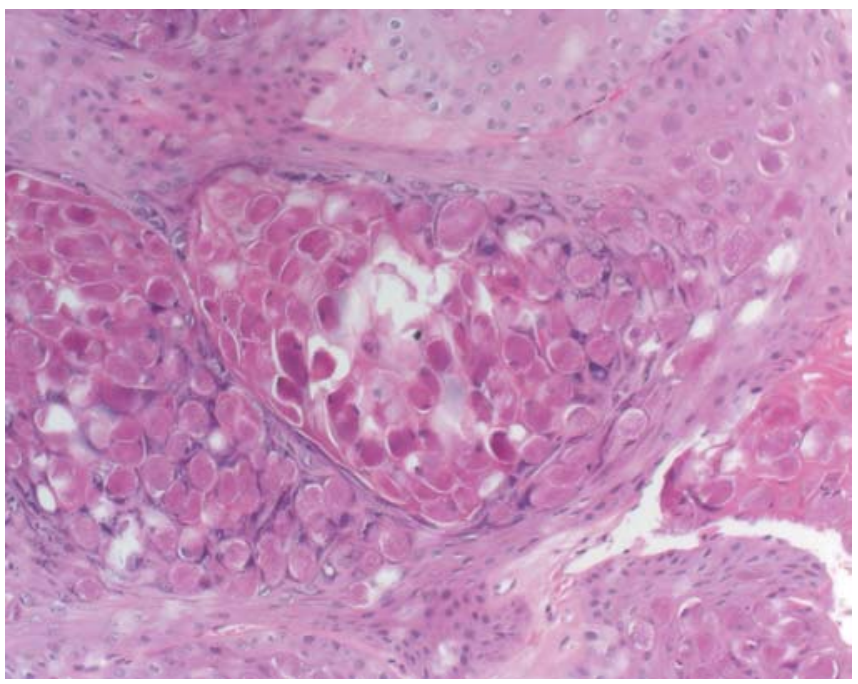

Fig. 4 Higher magnification showing intracytoplasmic eosinophilic structures, the so-called molluscum bodies. Neither the lesions nor the adjacent conjunctiva showed obvious signs of inflammation. $\mathrm{H} \& \mathrm{E}, \times 200$

\section{Discussion}

Molluscum contagiosum is the sole member of the genus Molluscipox and the last member of the Poxviridae family to specifically infect humans [13, 36]. MC infections received little attention until the advent of the AIDS epidemic, when extensive and recalcitrant MC lesions emerged as an important cause of disfigurement and morbidity [9, 31, 33, 51]. MC most closely resembles variolae vaccinus, sharing its characteristic ability to replicate entirely within the cytoplasm [36], and the feature of the restricted host range, with man being the only natural host that can support virus replication [36, 52]. Ocular manifestations of MC cover a broad spectrum. Apart from the well-known eyelid involvement, chronic follicular conjunctivitis [14], corneal micropannus and epithelial keratitis have also been described. Across Europe, Asia and South America, 12 cases of solitary conjunctival lesions have been reported $[1,6,12,21,26,27,43,54,57]$, but in only three instances were histopathological findings presented $[1,6,43]$. The treatment of MC in HIV-infected individuals is controversial. Local destructive techniques, such as excision, curettage [22], cryotherapy $[2,14]$, light electrodesiccation and laser therapy, [48], or handling with chemical agents, such as trichloroacetic acid peels [19], cantharidin [16] or podophyllotoxin ointment [56], are successful in healthy individuals but tend to fail in HIV-infected patients due to recurrence [31].

All previously documented cases of epibulbar MC have occurred in healthy, non-immunosuppressed patients [54]. To our knowledge, only one other case of bilateral conjunctival MC in an HIV-positive patient has been published to date [35]. That patient was a 40-year-old African man who had first tested seropositive for HIV 4 years previously, at which time he had a CD4 T-lymphocyte count of 70 cells $/ \mu l$. Infection was disseminated, with MC lesions being apparent on the face, the trunk and the genitalia; these had been treated repeatedly by curettage and cryotherapy within the preceding year. In our patient, no MC lesions were apparent within the lower or upper lids and perilesional conjunctival injection was minimal. Six months after the induction of HAART, the non-excised lesion in the right eye had undergone substantial regression and perilesional injection of the conjunctiva was marked, a sign that the cell-mediated immune function had recovered. Neither chronic follicular conjunctivitis nor eyelid involvement were apparent. In the left eye, excised lesions had not recurred.

In contrast to other poxviruses, MC invokes but a poor cellmediated immune response [52], an observation that has been corroborated at the molecular level. Senkevich et al. [52] demonstrated that of the 163 potential proteins encoded by the MC genome, 103 have homologues in the variola (smallpox) virus; however, MC lacks almost all of the variola virus genes that are responsible for host-virus interaction. Most investigators have reported infiltration of the normal dermis with T-lymphocytes to be poor around stable or eruptive MC lesions [25], but profuse around regressing [55] or traumatised [24] ones. Our own histological observations confirm these findings. Immunohistochemical analyses using T-cell markers revealed a mere scantling of T-lymphocytes within the subconjunctival stroma around MC lesions. In keeping with previous reports, which have shown MC lesions to be completely devoid of immunocompetent cells [25, 58], we likewise observed no T-cells within the lesions themselves; and perilesionally, only a few CD-68-positive macrophages were encountered. The scarcity of macrophages may relate to the circumstance that, whilst one of the MC-virus-coded proteins aligns with the human macrophage inflammatory protein $1-\beta$, it nevertheless lacks the $\mathrm{NH}_{2}$-terminus involved in monocyte activation [52]. Clinically, none of the lesions were obviously inflamed. Furthermore, molluscum bodies manifest no reactivity to the $\beta_{2}$-microglobulin [58]. This lack of expression of HLA class-I antigens may be related to the presence of three MC gene products which interfere with host defence.

The virtual absence of inflammatory cells from the neighbourhood of infected cells containing molluscum bodies in healthy as well as in immunocompromised individuals suggests that the cellmediated immune response within these lesions is ineffective, which may account for the chronicity. In contrast to the clinically obvious erythema and diffuse follicular conjunctivitis observed in immunocompetent persons, the conjunctival inflammatory reaction in immunocompromised patients may be comparatively mild or even clinically absent [30]. In immunocompetent individuals, MC lesions are limited in number and tend to remain stable or even to regress spontaneously, which suggests that the cell-mediated immune response is of borderline efficiency. In AIDS patients, 
however, MC lesions are numerous and tend to persist or recur, and the infection is frequently disseminated to other sites. This finding suggests that in immunocompromised individuals, the cell-mediated immune response is even less efficient than in immunocompetent ones. Against this background, it is therefore not surprising that MC can serve as a marker for advanced HIV infection [31, 45] and that the occurrence of this disease correlates statistically with a low CD4 T-lymphocyte count [20]. Perez-Blazquez et al. [41] have proposed that in advanced HIV infection, MC lesions of the eyelid occur when the CD4 T-lymphocyte count lies below 80 cells $/ \mu$ l.

It is not known whether the infection of HIV-positive individuals with MC represents de novo infection, acquired by bodily contact, or the reactivation of a latent condition [42]. MC is capable of inducing the formation of a variety of circulating antibodies [53], but the paucity of B-lymphocytes and of neutrophils and the tendency of recurrence suggest that humoral immunity plays but a minor role in the local immune response.

The effectiveness of treatment strategies in immunocompetent individuals may lie partially in the newly gained access of sensitised T-lymphocytes and other inflammatory cells to previously "walled off" virus-infected cells [7], a mechanism that is apparently not operative in HIV-positive patients. After the induction of HAART in individuals with advanced HIV infection, restoration of immune function [15] leads to a decrease in viral load and an increase in the CD4 T-lymphocyte count $[3,11]$. An inflammatory response could thereby be elicited within tissues infected by pathogens, such as CMV or myobacteria, a condition referred to as immune-restoration syndrome. In our patient, restoration of immune function carried the risk of an inflammatory response being mounted against the non-excised MC lesion (right eye), which could have led and still can lead to corneoscleral ulceration and ultimately to spontaneous perforation [60]. On the other hand, restoration of immunocompetence also accounted for the satisfactory postoperative course following the excision of lesions in the left eye-whereby local viral particles and antigens were removed-without local recurrence or severe inflammation. It is for these reasons that we opted to split the risk by performing surgery only in the eye that was more severely affected by MC.

This is the first documentation of a local inflammatory reaction in association with the spontaneous resolution of a MC lesion. This response is probably attributable to the restoration of immunocompetence by HAART.

In conclusion, physicians should be aware of the risks associated with the local persistence of antigen deposits before restoring immune function and should control their patients carefully with a view to averting local complications.

\section{References}

1. Ballaban T (1903) Molluscum contagiosum der Augapfelbindehaut. Arch Augenheilkd 47:180-186

2. Bardenstein DS, Elmets C (1995) Hyperfocal cryotherapy of multiple molluscum contagiosum lesions in patients with the acquired immune deficiency syndrome. Ophthalmology 102:10311034

3. Bartlett JG (1996) Protease inhibitors for HIV infection. Ann Intern Med 124:1086-1088

4. Bates CM, Carey PB, Dhar J, Hart CA (2001) Molluscum contagiosum-a novel presentation. Int J Std AIDS 12:614-615

5. Biswas J, Therese L, Kumarasamy N, Solomon S, Yesudian P (1997) Lid abscess with extensive molluscum contagiosum in a patient with acquired immunodeficiency syndrome. Indian $\mathrm{J}$ Ophthalmol 45:234-236

6. Charles NC, Friedberg DN (1992) Epibulbar molluscum contagiosum in acquired immune deficiency syndrome. Case report and review of the literature. Ophthalmology 99:1123-1126

7. Charteris DG, Bonshek RE, Tullo AB (1995) Ophthalmic molluscum contagiosum: clinical and immunopathological features. Br J Ophthalmol 79:476481

8. Chattopadhyay DN, Basak SK, Ghose S (1997) HIV-positive patient presented with giant molluscum contagiosum of the eyelid. J Indian Med Assoc 95:202
9. Cronin TA, Jr., Resnik BI, Elgart G, Kerdel FA (1996) Recalcitrant giant molluscum contagiosum in a patient with AIDS. J Am Acad Dermatol 35:266-267

10. Cursiefen C, Grunke M, Dechant C, Antoni C, Junemann A, Holbach LM (2002) Multiple bilateral eyelid molluscum contagiosum lesions associated with TNFalpha-antibody and methotrexate therapy. Am J Ophthalmol 134:270-271

11. Deeks SG, Smith M, Holodniy M, Kahn JO (1997) HIV-1 protease inhibitors. A review for clinicians. JAMA 277:145153

12. Denis J, Chauvaud D, Savoldelli M, Pouliquen Y (1978) Fine structure of palpebral molluscum contagiosum and its secondary conjunctival lesions. Albrecht Von Graefes Arch Klin Exp Ophthalmol 208:207-216

13. Fenner F (1990) Poxviruses. In: Knipe DM (ed) Virology, 2nd edn. Raven Press, New York

14. Fraunfelder FT, Wallace TR, Farris HE, Watkins J III, Hendrickson R, Smead WJ, et al (1977) The role of cryosurgery in external ocular and periocular disease. Trans Am Acad Ophthalmol Otolaryngol 83 (4 Pt 1):713-724

15. French MA, Lenzo N, John M, Mallal SA, McKinnon EJ, James IR, Price P, Flexman JP, Tay-Kearney ML (2000) Immune restoration disease after the treatment of immunodeficient HIV-infected patients with highly active antiretroviral therapy. HIV Med 1:107115
16. Funt TR, Mehr KA (1979) Cantharidin: a valuable office treatment of molluscum contagiosum. South Med J 72:1019

17. Ganpule M, Garretts M (1971) Molluscum contagiosum and sarcoidosis: report of a case. Br J Dermatol 85:587589

18. Garner A, Klintworth GK (1994) Pathobiology of ocular disease: a dynamic approach, 2nd edn. Dekker, New York

19. Garrett SJ, Robinson JK, Roenigk HH Jr (1992) Trichloroacetic acid peel of molluscum contagiosum in immunocompromised patients. J Dermatol Surg Oncol 18:855-858

20. Goldstein B, Berman B, Sukenik E, Frankel SJ (1997) Correlation of skin disorders with CD4 lymphocyte counts in patients with HIV/AIDS. J Am Acad Dermatol 36:262-264

21. Gomez M (1953) Sobre un caso de molluscum contagiosum con rara localizacion conjunctival. Arch Soc Oftal Hispano Am 13:684-685

22. Gonnering RS, Kronish JW (1988) Treatment of periorbital molluscum contagiosum by incision and curettage. Ophthalmic Surg 19:325-327

23. Goodman DS, Teplitz ED, Wishner A, Klein RS, Burk PG, Hershenbaum E (1987) Prevalence of cutaneous disease in patients with acquired immunodeficiency syndrome (AIDS) or AIDS-related complex. J Am Acad Dermatol 17:210-220

24. Henao M, Freeman RG (1964) Inflammatory molluscum contagiosum: clinicopathological study of seven cases. Arch Dermatol 90:479-483 
25. Heng MC, Steuer ME, Levy A, McMahon S, Richman M, Allen SG, Blackbart B (1989) Lack of host cellular immune response in eruptive molluscum contagiosum. Am J Dermatopathol 11:248-254

26. Hindaal CH, van Bijsterveld OP (1979) Molluscum contagiosum of the palpebral conjunctiva. Report of a case. Ophthalmologica 178:137-141

27. Ingraham HJ, Schoenleber DB (1998) Epibulbar molluscum contagiosum. Am J Ophthalmol 125:394-396

28. Katzman M, Carey JT, Elmets CA, Jacobs GH, Lederman MM (1987) Molluscum contagiosum and the acquired immunodeficiency syndrome: clinical and immunological details of two cases. Br J Dermatol 116:131-138

29. Khaskhely NM, Maruno M, Hoshiyama Y, Uezato H, Nonaka S (2000) Molluscum contagiosum appearing as a solitary lesion on the eyelid. J Dermatol 27:68-70

30. Kohn SR (1987) Molluscum contagiosum in patients with acquired immunodeficiency syndrome. Arch Ophthalmol 105:458

31. Koopman RJ, van Merrienboer FC, Vreden SG, Dolmans WM (1992) Molluscum contagiosum: a marker for advanced HIV infection. Br J Dermatol 126:528-529

32. Leahey AB, Shane JJ, Listhaus A, Trachtman M (1997) Molluscum contagiosum eyelid lesions as the initial manifestation of acquired immunodeficiency syndrome. Am J Ophthalmol 124:240-241

33. Lombardo PC (1985) Molluscum contagiosum and the acquired immunodeficiency syndrome. Arch Dermatol 121:834-835

34. Margo C, Katz NN (1983) Management of periocular molluscum contagiosum in children. J Pediatr Ophthalmol Strabismus 20:19-21

35. Merisier H, Cochereau I, Hoang-Xuan T, Toublanc M, Ruggeri C (1995) Multiple molluscum contagiosum lesions of the limbus in a patient with HIV infection. Br J Ophthalmol 79:393-394
36. Moss B (1990) Poxviridae and their replication. In: Knipe DM, et al (eds) Virology, 2nd edn. Raven Press, New York

37. Myskowski PL (1997) Molluscum contagiosum. New insights, new directions. Arch Dermatol 133:1039-1041

38. Pauly CR, Artis WM, Jones HE (1978) Atopic dermatitis, impaired cellular immunity, and molluscum contagiosum. Arch Dermatol 114:391-393

39. Peachey RD (1977) Severe molluscum contagiosum infection with $\mathrm{T}$ cell deficiency. Br J Dermatol 97:49-50

40. Pelaez CA, Gurbindo MD, Cortes C, Munoz-Fernandez MA (1996) Molluscum contagiosum, involving the upper eyelids, in a child infected with HIV-1. Pediatr AIDS HIV Infect 7:43-46

41. Perez-Blazquez E, Villafruela I, Madero S (1999) Eyelid molluscum contagiosum in patients with human immunodeficiency virus infection. Orbit 18:75-81

42. Petersen CS, Gerstoft J (1992) Molluscum contagiosum in HIV-infected patients. Dermatology 184:19-21

43. Ragni C, Carra G (1967) Mollusco contagioso congiuntivale di tipo tumorale. Giornale Medicina Militare 45:312-314

44. Reed RJ, Parkinson RP (1977) The histogenesis of molluscum contagiosum. Am J Surg Pathol1:161-166

45. Reynaud-Mendel B, Janier M, Gerbaka J, Hakim C, Rabian C, Chastang C, Morel P (1996) Dermatologic findings in HIV-1-infected patients: a prospective study with emphasis on CD4+ cell count. Dermatology 192:325-328

46. Rimbaud P, Izarn P, Meynadier J, Ravoire G (1996) Profuse eruption of molluscum contagiosum during lymphoid leukosis. Bull Soc Fr Dermatol Syphiligr 76:575-578

47. Robinson MR, Udell IJ, Garber PF, Perry HD, Streeten BW (1992) Molluscum contagiosum of the eyelids in patients with acquired immune deficiency syndrome. Ophthalmology 99:1745-1747

48. Rodenbach M, Gumbel H, Makabe R (1994) Laser therapy of eyelid and conjunctival tumors, especially in AIDS patients. Ophthalmologe 91:691-693
49. Rosenberg EW, Yusk JW (1970) Molluscum contagiosum. Eruption following treatment with prednisone and methotrexate. Arch Dermatol 101:439441

50. Sarma DP, Weilbaecher TG (1985) Molluscum contagiosum in the acquired immunodeficiency syndrome. J Am Acad Dermatol 13:682-683

51. Schwartz JJ, Myskowski PL (1992) Molluscum contagiosum in patients with human immunodeficiency virus infection. A review of twenty-seven patients. J Am Acad Dermatol 27:583588

52. Senkevich TG, Bugert JJ, Sisler JR, Koonin EV, Darai G, Moss B (1996) Genome sequence of a human tumorigenic poxvirus: prediction of specific host response-evasion genes. Science 273:813-816

53. Shirodaria PV, Matthews RS (1977) Observations on the antibody responses in molluscum contagiosum. Br J Dermatol 96:29-34

54. Sinha TR, Choudhary OP, Sinha PV (1984) Molluscum contagiosum (in conjunctiva). Indian J Ophthalmol 32:115

55. Steffen C, Markman JA (1980) Spontaneous disappearance of molluscum contagiosum. Report of a case. Arch Dermatol 116:923-924

56. Syed TA, Lundin S, Ahmad M (1994) Topical $0.3 \%$ and $0.5 \%$ podophyllotoxin cream for self-treatment of molluscum contagiosum in males. A placebo-controlled, double-blind study. Dermatology 189:65-68

57. Sysi R (1941) Molluscum contagiosum corneae. Acta Ophthalmol 19:25-27

58. Viac J, Chardonnet Y (1990) Immunocompetent cells and epithelial cell modifications in molluscum contagiosum. J Cutan Pathol 17:202-205

59. von Suzani C, Hazeghi P (1976) Infections transmitted in swimming pools. Soz Praventivmed 21:120-121

60. Williamson W, Dorot N, Mortemousque B, Leger F, Poirier L, Lacoste D, Verin P (1995) Spontaneous corneal perforation and conjunctival molluscum contagiosum in a AIDS patient. J Fr Ophtalmol 18:703-707 